\title{
STAN ZACHOWANIA SZESNASTOWIECZNYCH DRUKÓW BIBLIJNYCH Z KOLEKCJI BIBLIOTEKI FUNDACJI WIKTORA H. BAWOROWSKIEGO WE LWOWIE
}

\begin{abstract}
Streszczenie
Badanie stanu zachowania XVI-wiecznych druków biblijnych z kolekcji Biblioteki Fundacji Wiktora h. Baworowskiego we Lwowie przeprowadzono metodą opisową z autopsji. Ocenę każdego woluminu poszerzono dodatkowo o ocenę stopnia zakwaszenia papieru, zniszczenia biologiczne, a także wykonano prosty test na zginanie. Osobno oceniano uszkodzenia oprawy, konstrukcji książki i bloku starodruku. Po dokonaniu ocen cząstkowych egzemplarz klasyfikowano do jednej z czterech kategorii. Badaniu poddano 17 zachowanych egzemplarzy, spośród których 10 jest w nienajlepszym stanie zachowania i powinny zostać wyłączone z użytkowania. Papier pod względem wytrzymałości mechanicznej jest w bardzo dobrym stanie. Książki nie wymagają odkwaszania. Na podstawie wizualnej analizy zniszczeń biologicznych można stwierdzić, że księgozbiór w przeszłości nie był przechowywany w najlepszych warunkach, o czym świadczą zniszczenia wywołane przez owady i grzyby, a także zaplamienia i zacieki na papierze.
\end{abstract}

Słowa kluczowe: druki biblijne; Biblia; ocena stanu zachowania

\section{Wprowadzenie}

Biblioteka Fundacji Wiktora hr. Baworowskiego ${ }^{1}$ należała do najznakomitszych bibliotek XIX i początku XX wieku z uwagi na swoje zbiory budzących żywe zainteresowanie świata naukowego. Jej założyciel, Wiktor Baworowski (1826-1894), odebrał staranne wykształcenie, ukończył studia uniwersyteckie we

* Tadeusz Maciąg - mgr biologii; pracownik Zakładu Ochrony i Konserwacji Zbiorów Bibliotecznych, Instytut Nauk o Kulturze, Uniwersytet Śląski; e-mail: tadeusz.maciag@us.edu.pl https://orcid.org/0000-0002-3234-3951

${ }^{1}$ A. Łakomy-Chłosta, K. Makles: Zarys kształtowania się księgozbioru Biblioteki Fundacji Wiktora Hr. Baworowskiego we Lwowie, „Bibliotheca Nostra. Śląski Kwartalnik Naukowy”, 4 (2018) s. 31. 
Lwowie ${ }^{2}$, znał języki: francuski, niemiecki i angielski, krótko pracował w Namiestnictwie Galicyjskim ${ }^{3}$. Pod wpływem nauczycieli, znajomych i przyjaciół (m.in. Jana Nepomucena Kamińskiego) zainteresował się działalnością translatorską i pisarską ${ }^{4}$. Praca literacka i zgłębianie się w studia nad kulturą narodową rozbudziły w W. Baworowskim zamiłowanie kolekcjonerskie. Od 1850 roku, za namową bibliofila Aleksandra Batowskiego, rozpoczął gromadzenie książek, rękopisów, dyplomów, obrazów, rycin polskich i dotyczących dziejów i kultury Polski. Kupował pojedyncze egzemplarze, a także całe kolekcje, m.in. Stadnickich ze Żmigrodu, Ewarysta i Józefa Kuropatnickich,

[Kazimierza] Strończyskiego zbiór rękopismów [...] Grabowskiego Ambrożego rękopisma, Leona Dembowskiego kasztelana rzadkie druki, Zubrzyckiego Rusina, autora kronik miasta Lwowa druki i rękopisma, a także obrazy i sztychy, nabyte od Krasickich i Kazimierza Stadnickiego ${ }^{5}$.

Bardzo cennym nabytkiem który trafił w ręce hrabiego w 1852 roku były różnorodne dokumenty biblioteczne od Aleksandra Batowskiego: kilka tysięcy druków, kolekcja czasopism emigracyjnych, ponad 100 rękopisów, wiele rycin dotyczących historii Polski, polonica z XVI i XVII wieku z zakresu historii teologii, prawa polskiego i dawnej literatury polskiej. W skład zbioru A. Batowskiego wchodziła również kolekcja Konstantego Macewicza: portrety królów, wodzów, wybitnych Polaków. Zdobył ponadto 60 rękopisów Alojzego Osińskiego - członka Warszawskiego Towarzystwa Przyjaciół Nauk. Znajdowały się wśród nich prace o Piotrze Skardze, Tadeuszu Czackim, słowniki, listy Śniadeckiego, Kołłątaja i in. Trafiły także do jego zbiorów prace sanskrytologa Walentego Skorochód Majewskiego, Adolfa Łączyńskiego (literatura francuska) ${ }^{6}$.

W zbiorach znajdowały się m.in. najcenniejsze rękopisy średniowieczne (Kronika Wincentego Kadłubka, statuty Kazimierza Wielkiego) oraz listy i autografy Juliana Ursyna Niemcewicza, Jana Śniadeckiego, Aleksandra Fredry i Stanisława

${ }^{2}$ [W. Konopczyński], Baworowski hr. Wiktor, w: Polski Stownik Biograficzny, t. 1., Kraków: 1935, s. 368-370.

${ }^{3} \mathrm{Na}$ temat edukacji W. Baworowskiego i początków jego pasji bibliofilskich zob. J. Gwioździk: Podstawy Organizacji bibliotek Fundacji Wiktora hr. Baworowskiego we Lwowie, „Bibliotheca Nostra. Śląski Kwartalnik Naukowy", 4 (2018) s. 13-15.

4 Tłumaczył dzieła m.in. Byrona, Johanna Wolfganga Goethego, Friedricha Schillera, Gottfrieda Augusta Bürgera, Ludwiga Uhlanda), Wiktora Hugo, Jacques-Melchiora Villefranche', a także Horacjusza. Na ten temat zob. M. Eberharter: Wiktor hr. Baworowski: bibliofil i tlumacz, „Rocznik Przekładoznawczy. Studia nad teorią, praktyką i dydaktyką przekładu”, 12 (2017) s. 103, a zwłaszcza tenże: Die translatorischen Biographien von Jan Nepomucen Kamiński, Walenty Chtędowski und Wiktor Baworowski. Zum Leben und Werk von drei Literaturübersetzern im 19. Jahrhundert, Warschau 2018.

${ }_{5}^{5}$ Autobiografia Wiktora Baworowskiego [1826-1894], ze spisem prac i charakterystyką zbiorów Biblioteki Baworowskich we Lwowie. Biblioteka Jagiellońska rkps 6161 III, k. 6. Dostępne: Jagiellońska Biblioteka Cyfrowa, https://jbc.bj.uj.edu.pl/dlibra/doccontent?id=284462 (dostęp: 28.02.2020).

${ }^{6}$ J. Szocki, Księozbiór Wiktora Baworowskiego - lwowskiego kolekcjonera i fundatora biblioteki, w: Lwów, miasto, społeczeństwo, kultura, t. 2. red. H.W. Żaliński, K. Karolczak, Kraków 1998, s. 450 
Konarskiego. W zbiorze była reprezentowana w znacznej liczbie i najrzadszych wydaniach literatura piękna, polityczna, prawnicza, heraldyczna, liturgiczna, teologiczna, kaznodziejska, matematyczno-astronomiczna i przyrodnicza z wieków XVI i XVII. Reprezentowana była obficie literatura polemiczna, religijna i apologetyczna dysydentów ${ }^{7}$.

Na wzór Ossolineum W. Baworowski planował utworzyć Zakład Naukowy i Muzeum Fundacji Wiktora hr. Baworowskiego w Tarnopolu oraz Bibliotekę Fundacji Wiktora hr. Baworowskiego we Lwowie. Pierwotnie zbiory były lokowane Myszkowcach pod Tarnopolem, a w 1861 roku bibliotekę w całości przeniesiono do Lwowa do XVII-wiecznego gmachu dawnego arsenału, który wzniósł Mikołaj z Granowa Sieniawski. Budynek kupił Józef hr. Baworowski od Katarzyny Zimorowiczówny, a w 1854 roku odziedziczył go jego syn. W pierwszej połowie XIX wieku dawny arsenał został przebudowany na bibliotekę. W 1861 roku w bibliotece umieszczono 1500 tomów rękopisów, 10000 rycin ze zbioru Batowskiego, ok. 300 obrazów malarzy włoskich, niemieckich, holenderskich i polskich, ok. 200 dokumentów pergaminowych oraz ok. 15000 druków polskich i zagranicznych, a także autografy, rzeźby, okazy starej broni, porcelany, numizmaty, zegary i inne pamiątki ${ }^{8}$. W następnych latach regularne zakupy wzbogacały zasób biblioteki, co spowodowało, że w 1894 roku w jej zasobach znalazło się aż 15571 tomów druków, 1800 rękopisów, 110 dyplomów i 10000 rycin?

Po zgonie fundatora administrowanie biblioteką przejął Wydział Krajowy (rząd Galicji autonomicznej), w 1897 roku powstała instytucja Biblioteka Fundacji Wiktora hr. Baworowskiego we Lwowie, od 1900 roku udostępniona publiczności ${ }^{10}$, pod kierunkiem Józefa Korzeniowskiego, a następnie od 1905 roku Edmunda Sas-Naganowskiego, a po jego śmierci, w latach 1916-1940, Rudolfa Kotuli $^{11}$.

Biblioteka, zgodnie z testamentem i statutem założyciela, powiększała się o kolejne, przejmowane w całości zbiory. Wśród nich najświetniejszy był księgozbiór zakupiony po Zygmuncie hr. Czarneckim, liczący 6435 dzieł. Była to jedna z najcenniejszych i najciekawszych kolekcji, dokumentujących polską kulturę umysłową, założona w 1805 r. w Rusku przez Antoniego Czarneckiego ${ }^{12}$.

Przed wybuchem II wojny światowej stan zbiorów wynosił: 40000 tomów (w tym 6228 starych druków z XVI-XVII wieku, 35 inkunabułów), 1283 rękopisy, 500 dyplomów, ponad 10000 rycin oraz zbiór starych map. Pod koniec wojny zostały one rozproszone. Trafiły częściowo do Warszawy (Archiwum Główne Akt

${ }^{7}$ R. Kotula, Bibljoteka Wiktora Baworowskiego we Lwowie, Lwów 1926, s. 10

8 J. Gwioździk, Podstawy organizacji bibliotek Fundacji Wiktora hr. Baworowskiego we Lwowie, „Bibliotheca Nostra. Śląski Kwartalnik Naukowy”, (2018) nr 4, s. 21-22.

${ }^{9}$ A. Łakomy-Chłosta, K. Makles, Zarys kształtowania się księgozbioru Biblioteki Fundacji Wiktora Hr. Baworowskiego we Lwowie. „Bibliotheca Nostra. Śląski Kwartalnik Naukowy”, (2018) nr 4, s. 32-33.

${ }^{10}$ Kotula, Bibljoteka Wiktora Baworowskiego, s. 7.

${ }^{11}$ Tamże, s. 9.

12 J. Gwioździk, Druki z 1. połowy XVI w. z kolekcji Zygmunta Czarneckiego w zbiorach lwowskich, „Bibliotheca Nostra.”, (2014) nr 4, s. 71 
Dawnych i Biblioteka Narodowa) i Wrocławia, jednak zdecydowana większość pozostała na Ukrainie (według szacunkowych danych ok. 98\%) ${ }^{13}$.

W księgozbiorze warto wyróżnić zgromadzony zbiór edycji Biblii. Księga ta miała olbrzymie znaczenie dla ludzkiej myśli i działania, inspiracje nią są widoczne w literaturze, rzeźbie, malarstwie, architekturze i wielu innych dziedzinach aktywności intelektualnej. Jest najbardziej znaną i wydawaną księgą świata ${ }^{14}$, szacuje się, że od czasów wynalezienia druku osiągnęła ponad 4,7 miliarda egzemplarzy ${ }^{15}$, została przetłumaczona na ok. 2000 języków.

Spora liczba egzemplarzy Biblii w zbiorach Bavorovianum świadczy o przemyślanym gromadzeniu cymeliów, takich jak egzemplarz Biblii „cum concordantijs Veteris et Novi Testamenti et Novi Testamenti” wydany w Wenecji, łacińsko-polskie edycje opracowane przez Walentego Wróbla, drukowane z przedmową Andrzeja Glabera z Kobylina przez Floriana Unglera, Hieronima Wietora i Macieja Scharffenbergera. Zwraca także uwagę Zoltarz Dawidów przez Mistrza Walentego Wrobla ... polska mowa wytożony.

W XVI wieku ukazały się w Polsce fundamentalne przekłady Biblii w języku polskim dla każdej z grup wyznaniowych: katolików, protestantów i prawosławnych ${ }^{16}$. Był to okres bogaty w tłumaczenia Pisma Świętego, które stanowią większość ówczesnego polskiego piśmiennictwa ${ }^{17}$. Po złotym okresie renesansu i wydanych w tym czasie pierwszych pełnych przekładach Pisma Świętego w języku polskim zmalało zainteresowanie wydawaniem nowych tłumaczeń - bazowano na edycjach już istniejących (głównie Biblii ks. Jakuba Wujka z 1599 roku i protestanckiej Biblii Gdańskiej z 1632 roku) ${ }^{18}$.

$\mathrm{W}$ artykule przedstawiono stan zachowania 17 druków biblijnych wydanych w XVI wieku, do których zaliczamy publikacje zawierające większe fragmenty tekstów biblijnych, całe księgi, zbiory ksiąg, tzw. Ewangelie i epistoły, czyli antologie tekstów liturgicznych, komentarze biblijne, Nowe Testamenty i oczywiście pełne edycje Bibliii ${ }^{19}$.

Druki te obecnie znajdują się w zbiorach Biblioteki Fundacji Wiktora hr. Baworowskiego we Lwowskiej Bibliotece Naukowej im. W. Stefanyka Narodowej Akademii Nauk Ukrainy. Stanowią one ważny element wspólnego dziedzictwa, które należy przekazać następnym pokoleniom. W tej sytuacji znaczenia nabiera ocena zachowania tych druków.

\footnotetext{
${ }^{13}$ A. Chamera-Nowak A, Baworovianum. ,Cenne, Bezcenne, Utracone”, 3 (2011) s. 35.

${ }^{14}$ Oblicza Księgi. Biblia na przestrzeni wieków, red. P. Tkaczyk, Kielce 2009, s. 50.

${ }^{15}$ Tamże.

${ }^{16}$ B. Bieńkowska, Książka na przestrzeni dziejów. Warszawa 2005, s. 91.

${ }^{17}$,Nadolski, Dokoła prac..., s. 475.

${ }^{18}$ Od Biblii Wujka do wspótczesnego języka religijnego: Z okazji 400-lecia wydania Biblii ks.
} Jakuba Wujka, red. Z. Adamek, S. Koziara, Tarnów 1999, s. 11.

${ }^{19}$ R. Pietkiewicz, Pismo Święte w języku polskim w latach 1518-1638. Sytuacja wyznaniowa $w$ Polsce a rozwój edytorstwa biblijnego, Wrocław 2002, s. 4, mps. 


\section{Stan zachowania badanych woluminów}

Badanie stanu zachowania druków biblijnych z lat 1501-1600 przeprowadzono metodą opisową z autopsji. Posłużono się oceną pojedynczego egzemplarz zaproponowaną w metodzie stanfordzkiej ${ }^{20}$, opracowanej na Uniwersytecie w Stanford (USA) i Uniwersalnej Procedurze Oceny Bibliotek (UPLA) ${ }^{21}$, opracowanej przez Fundacje Bibliotek Dziedzictwa Flandryjskiego. Ocenę każdego woluminu poszerzono dodatkowo o ocenę stopnia zakwaszenia papieru, wykonując pomiar $\mathrm{pH}$, zniszczenia biologiczne, a także wykonano prosty test na zginanie. Osobno oceniano uszkodzenia oprawy, konstrukcji książki i bloku starodruku.

Po dokonaniu ocen cząstkowych egzemplarz klasyfikowano do jednej z czterech kategorii: obiekty $\mathrm{w}$ bardzo dobrym stanie (kategoria 1), obiekty lekko uszkodzone (kategoria 2), obiekty umiarkowanie zniszczone (kategoria 3), obiekty mocno zniszczone (kategoria 4).

Przy ocenie stanu zachowania oprawy książki brano pod uwagę:

1. Oprawę książki - kurz i zabrudzenia powierzchniowe, zniszczenia powierzchni okładzin, grzbietu, narożników, przegubów, występowanie reperacji, luźne lub brakujące części okładki, uszkodzone zapięcia i okucia.

2. Konstrukcję książki - uszkodzenia szycia (luźne, oddzielające się od bloku kartki, luźne szycie), zwięzów, odkształcenie okładek i bloku książki, brak okładzin, grzbietu.

3. Blok książki - kurz i zabrudzenia powierzchniowe kart papierowych, występowanie reperacji, rozdarcia, ubytki, zagięcia kart, posklejane karty, zakwaszenie papieru, foxing.

Kwalifikowanie obiektów do poszczególnych kategorii:

Kategoria 1 - obiekty w bardzo dobrym stanie, brak zauważalnych uszkodzeń, ewentualnie bardzo lekkie uszkodzenia niemające wpływu na użytkowanie obiektu.

Kategoria 2 - obiekty lekko uszkodzone, jedno lub dwa zauważalne uszkodzenia (np. szycie luźne, karty nie wypadają z bloku, powierzchnia okładek delikatnie wytarta, narożniki lekko uszkodzone), użytkowanie obiektu nie zwiększy jego uszkodzenia.

Kategoria 3 - obiekty umiarkowanie zniszczone, zestaw zauważalnych uszkodzeń w średnim lub dużym stopniu (luźne pojedyncze karty, nieznaczne ubytki w okładzinach, grzbiet, przeguby lekko uszkodzone) ograniczających użytkowanie książki i grożących w wypadku udostępniania czytelnikom pogorszeniem stanu zachowania.

${ }^{20}$ S. Buchanan, S. Coleman, Deterioration Survey of the Stanford University Libraries Green Library Stack Collection, w: Preservation Planning Program, Resource Notebook, ed. P.A. Darling, Washington 1982 oraz J. Palm, P. Cullhed, Papierqualität: Eine vergleichende Studie zur Schadensfeststellung an den Beständen der Universitätsbibliothek von Uppsala, w:, „Restauro: Zeitschrift für Kunsttechniken, Restaurierung und Museumsfragen“, 94 (1988) no 1, S. 38-43.

${ }^{21}$ S. Capiau, M. de Valk, E. Wuyts, The Universal Procedure for Library Assessment: A statistical model for condition surveys of special collections in libraries, "International Federation of Library Associations and Institutions", (2015) vol. 41 (3), 265-271 oraz M. de Valk, Library Damage Atlas. A tool for assessing damage, Antwerp 2018. 
Kategoria 4 - obiekty mocno zniszczone, (brak oprawy, oderwane jedna lub obie okładki, uszkodzenia szycia i zwięzów, ubytki w bloku książki, pęknięcie papieru po teście na zginanie), obiekty nie nadają się do użytkowania.

\section{Opis bibliograficzny/opis uszkodzeń każdego druku}

1. Biblia cu[m] concordantiis veteris et novi testamenti... / per... fratre[m] Alber$\mathrm{tu}[\mathrm{m}]$ castellanu[m] venetu[m] [...] revisa correcta eme[n]data [...] comparata et collata. - Venetiis impressa : per... Lucamantonium de Giunta, 1511. -[22], 519 [właśc. 518], [30] k. : il.; 4 . - Druk dwubarwny. - Prowieniencje. - Marginalia. - BJ 16-B-562. - Oprawa: wtórna, XIX-wieczna, oprawa typu półskórek, organiczna, okładziny tekturowe obleczone papierem marmuryzowanym; skóra z przetarciami na krawędziach i ubytkami w narożnikach, papier marmuryzowany z przetarciami na krawędziach. - Konstrukcja książki: w dobrym stanie. - Blok książki: wiele kart z załamaniami krawędzi, przetarciami i drobnymi ubytkami; zachowany fragment karty tytułowej, reperacje kart, zaplamienia, zażółcenie kart znaczne. - CT II 21585

2. Biblia to iest kxięgi Starego y Nowego Zakonu, ná polski ięzyk, z pilnośćią według lacinskiey Bibliey od kościoła krześcianskiego powssechnego przyiethey, nowo wyłoźona. - W Krakowie : w Drukarni Szarffenbergerow, 1561. - [470], [146] k. : il. ; $2^{\circ}$. - Prowieniencje. - E XIII, 13-14, Boh. 159. Oprawa: wtórna, XIX-wieczna, oprawa typu półskórek, organiczna, okładziny tekturowe obleczone papierem marmuryzowanym, skóra z przetarciami na krawędziach grzbietu i narożnikach, papier marmuryzowany, uszkodzony na krawędziach i przetartym licem. - Konstrukcja książki: w dobrym stanie. - Blok książki: karta tytułowa silnie zabrudzona z reperacjami ubytków, w bloku książki karty mocno zniszczone z zaciekami i zaplamieniami, liczne reperacje. - CT IV 50773

3. Nowy Testament to iest wszytkie pisma Nowego Przymierza / z greckiego ięzyka na rzecz połską wiernie y szczerze przełożone [przez Marcina Czechowica]. Przydane iest rozne czytanie na brzegach, ktore się w inszych księgach nayduie [...] - [Kraków] : drukował Alexius Rodecki, 1577. - [389] k.; $4^{\circ}$. - Prowieniencje. - Marginalia. - E XIII, 30; Boh. 171. - Oprawa: oryginalna, XVI-wieczna, organiczna, szyta na trzy podwójne zwięzy sznurkowe, okładziny drewniane obleczone brązową skórą, zachowane dwa zaczepy, skóra wytarta, ze spękaniami lica i nielicznymi ubytkami, skóra na grzbiecie spękana. - Konstrukcja książki: uszkodzona wyklejka tylna. - Blok książki: karty pofałdowane, z postrzępionymi krawędziami i drobnymi załamaniami narożników. - CT II 79671

4. Nowy Testament Pana naszego Iesvsa Christvsa, znowu z lacińskiego y z gr[a] eckiego na polskie wiernie [...] przełożony y argumentami Abo summariuszami każdych ksiąg y rozdziałow y annotacyami [...] obiaśniony, przydane są nauki y przestrogi mało nie za każdy[m] rozdziałem, porównanie Ewangelistow SS. y drogi rozmaite Piotra y Pawła S [....] / przez [...] Iakuba Wuyka [...] - W Krakowie: w drukarni Andrzeia Piotrkowczyka, 1593. - [1] k., 41, [1], 890 [właść. 891] s., [28] k. ; 4.- Prowieniencje - E XIII, 24, Boh. 174. 
- Oprawa: oryginalna, XVI-wieczna, organiczna, szyta na trzy podwójne zwięzły sznurkowe okładziny drewniane obleczone brązową ciemną skórą, zachowane zaczepy i okucia w narożnikach, skóra przetarta ze spękaniami lica i nielicznymi ubytkami, skóra na grzbiecie spękana. - Konstrukcja książki: uszkodzony grzbiet, skóra rozdarta na przegubach z ubytkiem w dolnej części. - Blok książki: karty pofałdowane, drobne załamania na krawędziach kart. - CT II 79672

5. Nowy Testament Polskim iezykiem wyłożony, według doswiadssonego Lacinskiego textu, od Kosciola krzescianskiego przyietego. Ktemu przyłożono Lekcie y Proroctwa i stárego zakonu wzięte ktore przy Ewangeliach bywaia, czytane [...] - W Krakowie: u Dziedzicow Markusa Szarffenbergera, 1556. [8], 392, [20] k. : il. ; 4 . - Prowieniencje. - E XIII, 22-23; Boh. 165. - Oprawa: wtórna, XIX-wieczna, okładziny tekturowe obleczone pergaminem w bardzo dobrym stanie.- Konstrukcja książki: w dobrym stanie. - Blok książki: nieliczne reperacje, nieliczne karty zażółcone. - CT II 80083

6. Nowy Thestament z Greckiego na polski iezyk z pilnością przełożon. - Drukowano w Nieświżu : przez Daniela Drukarza, 1568. - [504] k. ; $8^{\circ}$. - Prowieniencje. - E XIII, 28; Boh. 1968. - Oprawa: częściowo oryginalna, organiczna, okładziny drewniane. Na okładzinach zachowana oryginalna skóra XVI-wieczna, oprawa po naprawach introligatorskich, lico skóry wytarte, liczne ubytki. - Konstrukcja książki: strona tytułowa oderwana. - Blok książki: nieliczne reperacje, nieliczne żółte zacieki kart. - CT I 77985

7. Psalteriu[m] Davidicu[m] = Zoltarz Dawidow / przez [...] Walantego Wrobla [...] na rzecz polską wyłożony. - Gracchoviae : in officina Matthie Scharffenberger, 1539. - [336] k. : il. ; $8^{\circ}$. - Druk dwubarwny. - E XV, 74; BJ 16B-655. - Oprawa: oryginalna, XVI-wieczna, organiczna, szyta na cztery podwójne zwięzy sznurkowe, okładziny drewniane obleczone brązową skórą, skóra wytarta ze spękaniami lica, drobnymi ubytkami w narożnikach, krawędziach i grzbiecie, znaczny ubytek skóry na tylnej okładzinie, ślady po zapinkach (jedna zapinka zrekonstruowana umieszczona w środku krawędzi). - Konstrukcja książki: brak dolnego fragmentu skóry na grzbiecie oprawy, pęknięcie między wyklejkami a grzbietem. - Blok książki: drobne ubytki w kartach, zagięcia kart w narożnikach, brzegi kart wytarte. - CT I. 21943

8. Zołtarz Dawidow / przez [...] Valanthego Wrobla [...] na rzecz polską wyłożony - Cracoviae : ex Offincia Ungleriana, 1539 . - [342] k. : il. ; 8 . - Prowieniencje. - E XV, 68; BJ 16-B-656 - Oprawa: wtórna, XVIII-wieczna, organiczna, szyta na cztery zwięzy, okładziny tekturowe obleczone brązową skórą, skóra z lekkimi zarysowaniami i przetarciami narożników. - Konstrukcja książki: w dobrym stanie. - Blok książki: reperacje nielicznych kart, karta tytułowa zabrudzona, na nielicznych kartach brązowe zaplamienia. CT I. 21941

9. Zoltarz Dawidow / przez [...] Walantego Wrobla [...] polską mową wyłożony. - Teraz z więtssą pilnością pismem lacińskiem y Polskiem wydrukowany 
[...] - Wybiyano Krakowie : przez Jeronima Wietora, 1540. - [6], 336 k.: il. ; $8^{\circ}$. - Prowieniencje. - Marginalia. - E XV, 68; BJ 16-B-658. - Oprawa: oryginalna, XVI-wieczna, organiczna, szyta na trzy podwójne zwięzy sznurkowe, okładziny drewniane obleczone brązową skórą, skóra licznymi ubytkami, ze spękaniami lica i rozdarciami na krawędziach, ślady po zapinkach. - Konstrukcja książki: skóra rozerwana na przegubach, odklejona od grzbietu bloku, luźne karty z tyłu bloku, pęknięcie między wyklejkami a grzbietem. - Blok książki: brak karty tytułowej, na nielicznych kartach brązowe zaplamienia, tylne katy z zaciekami. - CT I. 21976

10. Psalterium Davidis $=$ Zołtarz Dawidow / przez [...] Walantego Wrobla [...] na rzecz polską wyłożny. - Cracoviae : in officina Matthiae Scharffenberger, opera et impensis, 1543. - [8] k., 339, [1] k. : il. ; $8^{\circ}$ - Prowieniencje - Marginalia. - E XV, 69; BJ 16-B-659. - Oprawa: oryginalna, XVI-wieczna, organiczna, szyta na trzy podwójne zwięzły sznurkowe, okładziny drewniane obleczone brązową skórą, skóra wytarta, ze spękaniami lica, drobnymi ubytkami w narożnikach i krawędziach, skóra na grzbiecie mocno spękana z ubytkami w dolnej części grzbietu i wzdłuż przegubów, zachowane dwa zaczepy, brak zapinek. - Konstrukcja książki: skóra rozerwana na przegubach, szycie luźne, luźne karty z przodu bloku, pęknięcie między wyklejką przednią a grzbietem. - Blok książki: reperacje nielicznych kart, karty zabrudzone z drobnymi załamaniami narożników, powierzchnia kart zażółcona. - CT I. 21944

11. Zołtharz Dawidow / Przez Mistrza Walentego Wrobla [...] na rzecz Polską wyłożony. - W Krakowie: w drukarni Mikołaia Szarffenbergera,1567. [4], 344,[4] k. : il. ; $8^{\circ}$. - Prowieniencje. - Marginalia. - E XXXIII, 367; Jocher 2384. - Oprawa: wtórna, XVIII-wieczna, okładziny tekturowe obleczone pergaminem, $\mathrm{w}$ bardzo dobrym stanie. - Konstrukcja książki w dobrym stanie. - Blok książki: nieliczne reperacje, na pojedynczych kartach zaplamienia. CT I 78076

12. Zywot y Nauka Pana Naszego Iesu Christa Albo Ewangelia ze czterech iedna [...] / zebrana i wydana przez [...] Jakuba Wuyka... . - W Krakowie : W Drukarni Jakuba Sibeneychera, 1597. - [20] k, 391 s. : il. ; $8^{\circ}$. - Prowieniencje. - E XXXIII, 399-400; Boh. 2710. - Oprawa: wtórna, XIX-wieczna, okładziny tekturowe obleczone brązową skórą, w bardzo dobrym stanie. - Konstrukcja książki: szycie luźne. - Blok książki: karty tytułowa i brzegi kart zabrudzone, reperacje na kilki pierwszych kartach, wżery atramentowe na stronie tytułowej po zapiskach proweniencyjnych. - CT I 77986

13. Psałterz Dawidow, porządkiem Kościoła świętego Powszechnego [...] według postanowienia S. Concilium Trydentskiégo [...] rozłożony. - W Krakowie: W Drukarni Lazarzowey, 1579. - 779 s., [29] k. ; $8^{\circ}$. - Prowieniencje E XV, 71. - Oprawa: wtórna, XIX-wieczna, oprawa typu półskórek, organiczna, okładziny tekturowe obleczone papierem marmuryzowanym. Skóra z przetarciami i ubytkami na krawędziach, narożniki wytarte. - Konstrukcja książki: luźna ostatnia karta w bloku. - Blok książki: na kartach zacieki i zabrudzenia, ostania karta przedarta. - CT I 78142 
14. Psalterz Dawidow / Teraz z Łacińskiego, z Graeckiego y z Zydowskiego na Polski ięzyk z pilnością przełożony y Argumentami, y Annotacyami objaśniony / Przez D. Iakuba Wvyka [...] - W Krakowie : W Drukarni Andrzeia Piotrkowczyka, 1594. - [1] k, 26 s. [2] k, 283 k., [8] : il. ; 4․ - Prowieniencje. E XV, 76-77; Boh. 1999. - Oprawa: wtórna, XVII-XVIII-wieczna, obleczona pergaminem barwionym na czerwono, szyta na cztery zwięzy, pergamin zdeformowany z przetarciami lica i krawędzi. - Konstrukcja książki: luźna ostatnia karta w bloku. - Blok książki: karta tytułowa zabrudzona, zaplamienia górnych krawędziach kart, narożniki załamane. - CT II 75938

15. PsalterzDawidow/Przekladania Iana Kochanowskiego. - W Krakowie: W Drukarni Lazarzowey, 1586. - 216 s., ; $4^{\circ}$. - Prowieniencje. - Marginalia. - E XV, 72. - Oprawa: oryginalna, XVI-wieczna, organiczna, szyta na pięć pojedynczych sznurkowych zwięzów, okładziny drewniane obleczone brązową skórą, ślady po zapinkach, skóra mocno uszkodzona, ubytki na krawędziach i narożnikach, lico ze spękaniami. Konstrukcja książki: szycie luźne, pęknięty przegub przedni, odstająca grzbietówka, pęknięcie między wyklejką przednią a grzbietem. - Blok książki: karta tytułowa zabrudzona, zacieki i zabrudzenia na licznych kartach, narożniki załamane, przetarte brzegi.-CT II 75954/I-IV

16. Septem canonice epistole beatorum ap[osto]lo[rum] Jacobi, Petri, Joannis et iude. - [Cracoviae : Joannes Haller, 1518-1519]. - [18] k. ; 4 . - Prowieniencje. - Marginalia. - E XVI, 74; Boh. 394. - Oprawa: wtórna, XIX-wieczna, okładziny tekturowe obleczone brązowym papierem, lico papieru miejscami przetarte, narożniki rozwarstwione z załamaniami. - Konstrukcja książki: szycie luźne, luźne karty w bloku książki, pęknięcie między wyklejką przednią a grzbietem . - Blok książki: reperacje nielicznych kart, na pojedynczych kartach zaplamienia. - CT II. 21504

17. Melodiae na Psalterz polski / przez MikolaiaGomólke uczynione. - W Krakowie: w Drukarni Lazarzowey, 1580. - [2], 167 [właść. 170] k. ; 4º - Prowieniencje. - Marginalia. - E XVII, 230. - Oprawa: wtórna, XVII-XVIII-wieczna, obleczona pergaminem, lico pergaminu mocno wytarte, pęknięty przegub przedni, uszkodzone narożniki, nieliczne ubytki. - Konstrukcja książki: szycie luźne, pęknięty przegub przedni, pęknięcie między wyklejką przednią a grzbietem, okładana odstaje od bloku. - Blok książki: na kartach zacieki i zabrudzenia, reperacje na ostatniej karcie. - CT II 79412

Podział 17 analizowanych obiektów w ramach poszczególnych kategorii wygląda następująco:

kategoria $1-2$ stare druki

kategoria $2-5$ starych druków

kategoria 3-4 stare druki

kategoria 4-6 starych druków 
Spośród badanych egzemplarzy druków biblijnych w stanie ogólnie dobrym, umożliwiającym udostępnianie i użytkowanie jest 7 starodruków, a 10 wymaga działań konserwacyjnych i introligatorskich (zob. tab. 1).

Tabela 1. Stopień zakwaszenia, właściwości wytrzymałościowe, opis uszkodzeń biologicznych i przynależność obiektu do kategorii

\begin{tabular}{|c|c|c|c|c|}
\hline Obiekt & $\begin{array}{l}\text { Średnia } \\
\text { pH }\end{array}$ & $\begin{array}{c}\text { Test na } \\
\text { zginanie }\end{array}$ & Uszkodzenia biologiczne & Kategoria \\
\hline 1. & 7,23 & Zaliczony & $\begin{array}{l}\text { Owady - wydrążone nieliczne kanały } \\
\text { wzdłuż grzbietu bloku książki } \\
\text { Działalność grzybów - zaplamienia na } \\
\text { papierze w kolorze czarnym, szarym }\end{array}$ & Kategoria 2 \\
\hline 2. & 6,4 & Zaliczony & $\begin{array}{l}\text { Owady - wydrążone nieliczne kanały } \\
\text { w okładzinie przedniej } \\
\text { Działalność grzybów - na skórze przed- } \\
\text { niej okładziny białawy nalot grzybowy }\end{array}$ & Kategoria 3 \\
\hline 3. & 6,72 & Zaliczony & $\begin{array}{l}\text { Brak śladów działalności owadów i grzy- } \\
\text { bów }\end{array}$ & Kategoria 2 \\
\hline 4. & 6,75 & Zaliczony & $\begin{array}{l}\text { Brak śladów działalności owadów i grzy- } \\
\text { bów }\end{array}$ & Kategoria 4 \\
\hline 5. & 6,58 & Zaliczony & $\begin{array}{l}\text { Brak śladów działalności owadów i grzy- } \\
\text { bów }\end{array}$ & Kategoria 4 \\
\hline 6. & 7,23 & Zaliczony & $\begin{array}{l}\text { Brak śladów działalności owadów i grzy- } \\
\text { bów }\end{array}$ & Kategoria 3 \\
\hline 7. & 6,00 & $\begin{array}{l}\text { Niezali- } \\
\text { czony }\end{array}$ & $\begin{array}{l}\text { Owady - wydrążone nieliczne otwory } \\
\text { w bloku książki }\end{array}$ & Kategoria 4 \\
\hline 8. & 6,66 & Zaliczony & $\begin{array}{l}\text { Brak śladów działalności owadów i grzy- } \\
\text { bów }\end{array}$ & Kategoria 3 \\
\hline 9. & 6,15 & Zaliczony & $\begin{array}{l}\text { Działalność grzybów - na skórze przed- } \\
\text { niej okładziny białawy nalot grzybowy } \\
\text { Owady - wydrążone nieliczne otwory } \\
\text { w bloku ksiąziki i okładzinach }\end{array}$ & Kategoria 3 \\
\hline 10. & 6,27 & Zaliczony & $\begin{array}{l}\text { Brak śladów działalności owadów i grzy- } \\
\text { bów }\end{array}$ & Kategoria 1 \\
\hline 11. & 6,02 & Zaliczony & $\begin{array}{l}\text { Działalność grzybów - zaplamienia na } \\
\text { papierze w kolorze czarnym, szarym }\end{array}$ & Kategoria 3 \\
\hline 12. & 6,33 & Zaliczony & $\begin{array}{l}\text { Brak śladów działalności owadów i grzy- } \\
\text { bów }\end{array}$ & Kategoria 1 \\
\hline 13. & 6,02 & Zaliczony & $\begin{array}{l}\text { Brak śladów działalności owadów i grzy- } \\
\text { bów }\end{array}$ & Kategoria 2 \\
\hline
\end{tabular}




\begin{tabular}{|l|l|l|l|l|}
\hline 14. & 6,37 & Zaliczony & $\begin{array}{l}\text { Brak śladów działalności owadów i grzy- } \\
\text { bów }\end{array}$ & Kategoria 2 \\
\hline 15. & 6,04 & Zaliczony & $\begin{array}{l}\text { Brak śladów działalności owadów i grzy- } \\
\text { bów }\end{array}$ & Kategoria 2 \\
\hline 16. & 6,21 & Zaliczony & $\begin{array}{l}\text { Owady - na okładzinach wydrążone } \\
\text { nieliczne kanały i wzdłuż grzbietu bloku } \\
\text { książki ślady działalności owadów } \\
\text { Działalność grzybów - na pierwszej } \\
\text { i ostatniej karcie zaplamienia w kolorze } \\
\text { czarnym, szarym }\end{array}$ & Kategoria 4 \\
\hline 17. & 5,95 & Zaliczony & $\begin{array}{l}\text { Owady - wzdłuż grzbietu bloku książki } \\
\text { ślady działalności owadów }\end{array}$ & Kategoria 4 \\
\hline
\end{tabular}

\section{Stopień zakwaszenia badanych woluminów}

Substancje o charakterze kwaśnym występujące w papierze powodują zrywanie łańcuchów celulozy, która jest głównym składnikiem włókien roślinnych, a tym samym papieru. Depolimeryzacja celulozy następuje przede wszystkim wskutek hydrolizy, która zachodzi w środowisku kwaśnym. Zakwaszone papiery charakteryzują się znacznie zmniejszoną odpornością na rozrywanie, dużą łamliwością, zażółceniem, a ostatecznym efektem działania kwasów jest całkowita destrukcja papieru ${ }^{22}$.

Dla każdego obiektu wykonano oznaczenie $\mathrm{pH}$ papieru. Badanie $\mathrm{pH}$ wykonywano na trzeciej karcie, licząc od początku, w środku bloku i na 3 kracie, licząc od końca bloku książki. Na każdej karcie pH zbadano w trzech punktach. Dwa były zlokalizowane w narożnikach karty, a jeden w środku.

Oznaczenie odczynu papieru przeprowadzono metodą stykową ${ }^{23}$, w której dokonuje się pomiaru pH kropli wody, naniesionej na powierzchnię papieru. Do badania wykorzystano pH-metr Elmetron CX-741, z elektrodą zespoloną EPX-3 z opcją automatycznego ustalenia końca pomiaru. Stopień zakwaszenia zbioru przedstawiono w tabeli 1 .

Wartość zmierzonego pH świadczy o niewysokim zakwaszeniu. Średnia $\mathrm{pH}$ większości badanych książek zawiera się powyżej pH 6. Można przyjąć, że obiekty o pH powyżej tej wartości nie wymagają odkwaszania ${ }^{24}$, Jedynie obiekt 17 posiada średnie $\mathrm{pH}$ wynoszące poniżej $6 \mathrm{i}$ tylko w stosunku do niego należałoby przeprowadzić proces odkwaszenia papieru.

\section{Wlaściwości wytrzymałościowe}

Odporność papieru na zginanie jest jedną z jego cech wytrzymałościowych (mechanicznych). Podstawowym badaniem mechanicznym papieru zabytkowego

${ }^{22}$ W. Sobucki, Konserwacja papieru: zagadnienia chemiczne, Warszawa 2013, s. 150-151.

${ }^{23}$ PN-P50149:1981 Papier i tektura. Oznaczanie pH powierzchni metoda stykowa.

${ }^{24}$ W. Sobucki, Odkwaszanie papierów zabytkowych, „Ochrona Zabytków”, 54/1 (212) (2001) s. 67 
jest liczba podwójnych zgięć (lpz). Podwójnym zgięciem jest pełny cykl, polegający na tym, że próbka jest zginana najpierw do tyłu, a następnie do przodu. Zgięcie odbywa się wzdłuż tej samej linii ${ }^{25}$. Wykonany w trakcie badania test ręcznego zginania polegał na 10-krotnym zgięciu narożnika karty, a następnie jego lekkim napięciu. Wynik próby zależy od tego, czy narożnik ulegnie uszkodzeniu. Powyższy test pomyślnie przeszło 16 wolumenów. W obiekcie 7 nastąpiło oderwanie narożnika, co świadczy o tym, że papier jest słaby i pilnie wymaga wzmocnienia.

\section{Zniszczenia przez grzyby i owady}

Na 5 książkach (29\%) stwierdzono zniszczenia spowodowane przez wzrost i działanie grzybów pleśniowych. Klasycznymi objawami rozwoju tych mikroorganizmów jest występowanie nalotów: czarnych i puszystych lub brązowych, szarych i brudnozielonych, lub zaplamień na papierze w kolorze czarnym, szarym, brązowym, oliwkowym.

Wynikiem długotrwałego rozwój w papierze mikroorganizmów jest osłabienie jego struktury. Grzyby rozkładając celulozę i kleje, powodują w początkowej fazie kruchość i rozpulchnienie papieru, co w konsekwencji prowadzi do powstawania przedarć i ubytków w papierze ${ }^{26}$.

Badając woluminy, stwierdzono, że 6 egzemplarzy nosi ślady działalności owadów (35\%). Owady najintensywniej żerują w tych miejscach na książkach, które obfitują w klej, a więc w grzbietach i okładkach. Drążą tam głębokie kanały, wywołując osłabienie konstrukcji książki i widoczne zewnętrzne ślady ich działalności. W bloku książki larwy drążą korytarze stosowne do ich wielkości. Rezultatem żerowania owadów w książkach były ubytki papieru ${ }^{27}$.

\section{Podsumowanie}

Ocena stanu zachowania badanych druków biblijnych pokazała, że 10 woluminów jest w nienajlepszym stanie zachowania i powinny zostać wyłączone $\mathrm{z}$ użytkowania. Papier pod względem wytrzymałości mechanicznej jest $\mathrm{w}$ bardzo dobrym stanie. Test ręcznego zginania pomyślnie nie przeszedł papier tylko w jednym druku. Poza jednym egzemplarzem książki nie wymagają odkwaszania, ponieważ kwasowość papieru zbadanych obiektów wynosi powyżej $6 \mathrm{pH}$. Na podstawie wizualnej analizy zniszczeń biologicznych można stwierdzić, że księgozbiór w przeszłości nie był przechowywany w najlepszych warunkach, o czym świadczą zniszczenia wywołane przez owady i grzyby, a także zaplamienia i zacieki na papierze.

${ }^{25}$ B. Zyska, Trwałość papieru w drukach polskich z lat 1800-1994, Katowice 1999, s. 27-28.

${ }^{26}$ A.B. Strzelczyk, J. Karbowska-Berent, Drobnoustroje i owady niszczace zabytki, Toruń 2004, s. 105-110.

${ }^{27}$ A.B. Strzelczyk: Zbiory biblioteczne - przyczyny zniszczeń i możliwości zapobiegania tym procesom, „Folia Bibliologica”, 42-43 (1994/1995) s. 17. 


\section{BIBLIOGRAFIA}

\section{Źródła}

Biblioteka Jagiellońska

sygn. 6161 III, Autobiografia (1877). Autobiografia Wiktora Baworowskiego ze spisem prac i charakterystyką zbiorów Biblioteki Baworowskich we Lwowie.

PN-P50149:1981 Papier i tektura. Oznaczanie pH powierzchni metodą stykową.

\section{Opracowania}

Bieńkowska Barbara, Maruszak Elżbieta, Książka na przestrzeni dziejów, Warszawa 2005. Buchanan Sarah, Coleman Sandra, Deterioration survey of the Stanford University Libraries Green Library Stack Collection, w: Preservation Planning Program, Resource Notebook, ed. P.A. Darling, Washington 1982, s. 159-191.

Capiau Sam, Valk Marijn de, Wuyts Eva, The Universal Procedure for Library Assessment: A statistical model for condition surveys of special collections in libraries, „International Federation of Library Associations and Institutions", (2015) vol. 41(3), s. 265-271.

Gwioździk Jolanta, Podstawy organizacji bibliotek Fundacji Wiktora hr. Baworowskiego we Lwowie, „Bibliotheca Nostra. Śląski Kwartalnik Naukowy”, 4 (2018) s. 21-22.

Gwioździk Jolanta Druki z 1. połowy XVI w. z kolekcji Zygmunta Czarneckiego w zbiorach lwowskich, „Bibliotheca Nostra. Śląski Kwartalnik Naukowy”, (2014) nr 4, s. 71

Chamera-Nowak Agnieszka, Baworovianum, „Cenne, Bezcenne, Utracone”, 3 (2011) s. 35.

Kotula Rudolf, Bibljoteka Wiktora Baworowskiego we Lwowie, Lwów 1926.

Łakomy-Chłosta Agnieszka, Makles Karol, Zarys kształtowania się księgozbioru Biblioteki Fundacji Wiktora Hr. Baworowskiego we Lwowie, „Bibliotheca Nostra. Śląski Kwartalnik Naukowy", (2018) nr 4, s. 31

Nadolski Bronisław, Dokoła prac przekładowych w XVI wieku, „Pamiętnik Literacki”, 63 (1952) s. 475.

Oblicza księgi : Biblia na przestrzeni wieków, red. P. Tkaczyk, Kielce 2009.

Od Biblii Wujka do wspótczesnego języka religijnego. Z okazji 400-lecia wydania Biblii ks. Jakuba Wujka, red. Z. Adamek, S. Koziara, Tarnów 1999.

Palm Jonas, Cullhed Per, Papierqualität, Restauro 1988, t. 20.

Pietkiewicz Rajmund, Pismo Święte w języku polskim w latach 1518-1638. Sytuacja wyznaniowa w Polsce a rozwój edytorstwa biblijnego, Wrocław 2002, mps.

Sobucki Władysław, Odkwaszanie papierów zabytkowych, „Ochrona Zabytków”, 54/1 (212) (2001) s. 67.

Sobucki Władysław, Konserwacja papieru: zagadnienia chemiczne, Warszawa 2013.

Strzelczyk Alicja B., Karbowska-Berent Joanna, Drobnoustroje i owady niszczace zabyt$k i$, Toruń 2004.

Strzelczyk Alicja B., Zbiory biblioteczne - przyczyny zniszczeń i możliwości zapobiegania tym procesom, „Folia Bibliologica”, $42 / 43$ (1994/1995) s. 17.

Szocki Józef, Księgozbiór Wiktora Baworowskiego - lwowskiego kolekcjonera i fundatora biblioteki, w: Lwów, miasto, społeczeństwo, kultura, t. 2, red. H.W. Żaliński, K. Karolczak, Kraków 1998.

Valk Marijn de, Library Damage Atlas. A tool for assessing damage, Antwerp 2018.

Zyska Bronisław, Trwałość papieru w drukach polskich z lat 1800-1994, Katowice 1999. 
THE STATE OF PRESERVATION OF SIXTEENTH-CENTURY
BIBLE PRINTS FROM THE COLLECTION OF THE COUNT
WIKTOR BAWOROWSKI FOUNDATION LIBRARY IN LVIV

Summary

Evaluation of the preservation state of sixteenth-century biblical prints from the collection of the Count Wiktor Baworowski Foundation Library in Lviv was conducted using the descriptive method from the autopsy. The evaluation of each volume was additionally extended by the assessment of the degree of acidity of the paper, biological damage; a simple bending test was also performed. Damages to the binding, book structure and old print block were assessed separately. After the partial assessments, the copy was classified into one of four categories. 17 preserved copies were tested, of which 10 are in poor condition and should be taken out of service. The paper is in very good condition in terms of mechanical strength. The books require no deacidification. On the basis of a visual analysis of the biological damage, it can be concluded that the book collection was not stored in optimal conditions in the past, as evidenced by the damage caused by insects and fungi, as well as stains and streaks on paper.

Keywords: biblical prints; the Bible; preservation state evaluation

Translated by Marek Robak-Sobolewski 